\title{
牛コロナウイルス感染による成牛の伝染性下痢症の発生例
}

白石忠昭* 原田清志** 高瀬守史** 坦崎一則** 栗原宏治** 原 文男* 岩田明敏*

(昭和 54 年 9 月 21 日受理)

\section{Outbreaks of Diarrhea in Cows by Bovine Coronavirus Infection}

TAdaAki Shiraishi et al. (Animal Health Laboratory, Prefecture of Shimane, Izumo 693, et al.)

\section{SUMMARY}

Infectious diarrhea broke out on 7 and 2 farms in Shimane Prefecture in October, 1976, and November, 1977, involving 59 of 85 cows $(69.4 \%)$ and 43 of 76 cows $(56.6 \%)$, respectively. No virus was isolated from diarrheal feces in bovine kidney or bovine testicle cell cultures. When a survey was

島根県下に打いては, 従来から冬期, 成牛に一過性の 伝染性下痢症の発生がみられてきた。 とくに乳牛に叔い ては，泌乳量の著しい減少を伴うことから，その経済的 損失はきわめて甚大なものがあった。

いっぽう, 本症の原因としては, 発生状況, 臨床症状 などからウイルス感染症が強く疑われてきたが，原因ウ イルスを明らかにするまでには至らなかった。

高橋ら ${ }^{17)}$ は, 1976 年 11 月から 1977 年 2 月にかけ て, 静岡県, 千葉県など 6 県下で成牛に集団発生した下 痢症について, 各種検索を行なった結果, 本症の病因は 牛コロナウイルス（B C V)であることを明らかにした.

著者らも 1976 年 10 月および 1977 年 11 月の 2 度 にわたり，乳用牛を導入した酪農家に和いて，牛を導入 後, 在来の同居牛に集団発生した成牛の伝染性下痢症に 遭遇し, 各種検查を行なった結果, 血清学的に B C V 感 染が強く整われたので, その発生状況执よび検查成績に ついて報告する。

\section{材 料および方 法}

\section{1. 一 般 臨 床 検 查}

導入牛および在来の同居牛について臨床観察を行なら とともに, 下痢発症牛に和いては, 下痢便の性状和よび 下痢の持続日数などについて検査した.

発生例 1 の農家のらち 5 户 $(\mathrm{A} \sim \mathrm{E})$ に拈いて, 導入 後から下痢回復後約 4 週間の農家別総乳量の推移を調査 した.

発生例 1 の農家の 万ち 3 戸 $(\mathrm{A} \sim \mathrm{C})$, 計 7 頭の発症牛

* 島根県家畜衛生研究所(島根県出雲市神西沖町918-4)

**島根県江津家畜保健衛生所（島根県江津市江津町 1016-1) conducted on 11 cows for antibodies against 6 known pathological viruses, nine cows $(81.8 \%)$ showed a significant increase in titer of $\mathrm{HI}$ antibody against bovine coronavirus.

Diarrhea was transient, lasting for $2 \sim 3$ days, but it took $2 \sim 3$ weeks for recovery of milk yields.

について, 白血球数および白血球百分比の検査を行なっ た。

\section{2. 外気 温 の 調 查}

発生と外気温との関係を検討するための気温の調 査 は, 導入から発生の間に括ける発生地区の農業気像観測 所で測定された最高和よび最低気温の測定值によった.

\section{3. 病原検 索}

病原検索は発生例 1 の 7 頭, 発生例 2 の 4 頭の計 11 頭 の発症牛の下痢便を検査材料として, 牛腎 (BK) 抏よ び牛精巣（B T) の $2 \sim 3$ 代培養細胞によるウイルス分 離および $5 \%$ 牛血液加寒天括よびマッコンキー寒天培地 による細菌分離を試みた。

\section{4. 既知病原ウイルスに対する抗体検査}

癹生例 1 の 9 頭, 発生例 2 の 4 頭計 13 頭の発症牛の 発症中と回復後のペア血清について，6種の既知病原ウ イルスに対する抗体検査を行なった。すなわち，パライ ンフルェンザ 3 型ウイルス ( P I V-3), 牛アデノ 7 型ウ イルス $(\mathrm{AdV}-7)$, 牛ロタウイルス (B R V) 特よび B C V については, 血球凝集抑制 (H I ) 試験（マイクロタイ タ一法）により，牛伝染性鼻気管资ウイルス（I B R V) および牛ウイルス性下痢症ウイルス（BVDV）につい ては中和試験（マイクロプレート同時接種法）により行 なった。

抗 原：H I 試験用抗原は，P I V-3 および AdV-7 については, 市販の血球凝集 ( H A) 抗原を用い, B R V および B C Vについては, 農林水産省家畜衛生試験場よ り分与を受けた $\mathrm{HA}$ 抗原 ${ }^{4,13)}$ を用いた. 中和試験用ウイ ルスは, I BR Vについては, No.758 株 ${ }^{11)}$ 感染 B T 細

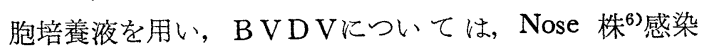
B T細胞培養液を用いた。 
白石忠昭 原田清志 高瀬守史 垣崎一則 栗原宏治 原 文男 岩田明敏

H I 試験：H I 試験の術式は, P I V-3 牡よびAdV-7 は稲葉の法 ${ }^{1)}$ ， B R V は INABA らの法4)，B C V はSATO らの法 ${ }^{13}$ により行なった。

中和試験：中和試験の術式は，I B R V は岸らの法7), B VDVは田中らの法 ${ }^{18}$ に準じて行なった。すなわち， $56^{\circ} \mathrm{C} 30$ 分間加熱非動化した可検血清をトランスファー プレート上にて， $0.025 \mathrm{ml}$ のダイリューターを用い，細 胞增殖用培養液 $\left(56^{\circ} \mathrm{C} 30\right.$ 分間加熱非働化した当該ウイル スの抗体陰性の子牛血清 $10 \%$, トリプトースフォスフェ 一トブロス $10 \%, 7.5 \% \mathrm{NaH} \mathrm{CO}_{3} 0.5 \%$ 扰よび抗生物質 を含んだイーグル MEM液）で 2 倍階段希釈し，各希积 液に $200 \mathrm{TCID}_{50} / 0.025 \mathrm{ml}$ のウイルス液を等量 $(0.025$ $\mathrm{m} l$ ) ずつ混合し, B V D Vは $37^{\circ} \mathrm{C}$ で 1 時間, I B R V は $37^{\circ} \mathrm{C}$ で 24 時間感作した. な拉, 血清の希釈列は 1 血清につき 2 列ずつ作った。ついで上記トランスファー プレートを，あらかじめ細胞増殖用培養液で $3 \sim 4 \times 10^{5}$ 個 $/ \mathrm{m} l$ に調製した B T細胞浮遊液を各穴に $0.1 \mathrm{~m} l$ ずつ 分注してあったマイクロタイタ一用平底プレート(Cook Engineering $\mathrm{Co}, \mathrm{USA})$ に移し, $37^{\circ} \mathrm{C} て ゙ 3 \sim 4$ 日間培養 した.

血清の中和抗体価は 2 穴のうち, 少なくとも 1 穴の細 胞変性効果（CP E）の出現を阻止した血清の最高希䣋 倍数で示した.

\section{検 查 成 績}

\section{1. 牛 の 導入 状 況}

発生例 1 に怙いては, 1976 年 10 月 27 日に 14 頭の初 妊牛が，浜田市・江津市和よび那賀郡二隅町の 9 戸の酪 農家へ, 発生例 2 亿执いては, 1977 年11月8 日に 20 頭 の初妊牛が, 邑智郡瑞穂町の11戸の酪農家へ, それぞれ北 海道の同一地区より同じトラックで導入された（表 1).

表 1 牛の導入および発生状況

\begin{tabular}{|c|c|c|}
\hline & 発生例 1 & 発生例 2 \\
\hline 導入年月日 & 1976.10 .27 & 1977.11. 8 \\
\hline 導入農家戸数 & 9 戸 & 11戸 \\
\hline 導入頭数 & 14頭 & 20 頭 \\
\hline 初発年月日 & 1976.10 .29 & 1977.11 .15 \\
\hline 発生農家戸数 & 7 戸 $(\mathrm{A} \sim \mathrm{G})$ & 2 戸 $(\mathrm{H}, \mathrm{I})$ \\
\hline $\begin{array}{c}\text { 発生農家における } \\
\text { 在来牛頭数 }\end{array}$ & 85 頭 & 76 頭 \\
\hline 発生頭数 (発生率) & 59 頭 (69.4\%) & 43 頭 $(56.6 \%)$ \\
\hline 下痢の持続日数 & $2 \sim 5$ 日 & $2 \sim 3$ 日 \\
\hline
\end{tabular}

\section{2. 発 生 状 況}

下痢の初発は, 発生例 1 飞括いては, 導入 2 日後の 10 月 29 日, 発生例 2 飞括いては, 7 日後の 11 月 15 日 であった. 発生は導入農家 9 戸のらち 7 戸 (発生例 1 ) および 11 戸のらち2 戸（発生例 2) にみられた。 これ ら発生農家に执いては, 在来の同居牛にの夕発生が夕ら
れ，導入牛には 1 頭もみられなかった。発生頭数は発生 例 1 では 85 頭中 59 頭 $(69.4 \%)$, 発生例 2 では 76 頭 中 43 頭 (59.6\%) であった(表 1).

また，農家別発生率は，農家間に大きな差がみられた が，発生例 1 の 2 戸拉よび発生例 2 の 9 戸の農家では発 生がみられなかった。

導入から初発までの日数は, 短かい農家で 2 日, 長い 農家で 15 日であった(表 2 ).

$$
\text { 表 } 2 \text { 農 家 別 発生状 況 }
$$

\begin{tabular}{|c|c|c|c|c|c|c|}
\hline \multirow{2}{*}{$\begin{array}{l}\text { 農 } \\
\text { 家 }\end{array}$} & \multirow{2}{*}{$\begin{array}{l}\text { 導入後初 } \\
\text { 発玉での } \\
\text { 日数 }\end{array}$} & \multicolumn{2}{|c|}{ 導入牛 } & \multicolumn{3}{|c|}{ 在 来 牛 } \\
\hline & & 頭数 & 発生頭数 & 頭数 & 発生頭数 & 発生率 \\
\hline & (日) & & & & & $(\%)$ \\
\hline A & 5 & 3 & 0 & 11 & 9 & 81.8 \\
\hline B & 2 & 2 & 0 & 8 & 8 & 100 \\
\hline $\mathrm{C}$ & 9 & 1 & 0 & 6 & 6 & 100 \\
\hline $\mathrm{D}$ & 13 & 1 & 0 & 21 & 12 & 57.1 \\
\hline $\mathrm{E}$ & 4 & 2 & 0 & 11 & 11 & 100 \\
\hline $\mathrm{F}$ & 5 & 1 & 0 & 10 & 10 & 100 \\
\hline $\mathrm{G}$ & 9 & 2 & 0 & 18 & 3 & 16.7 \\
\hline $\mathrm{H}$ & 7 & 1 & 0 & 53 & 41 & 77.4 \\
\hline $\mathrm{I}$ & 15 & 1 & 0 & 23 & 2 & 8.7 \\
\hline
\end{tabular}

\section{3. 臨 床 所見}

臨床症状としては, 元気消失, 食欲減退ないし癈絶, $40 \sim 42^{\circ} \mathrm{C}$ の発熱, 激しい下痢, 泌乳量の減少などがみら れ, 一部に水様性鼻汁, 発咳もみられた. 熱は $1 \sim 3$ 日 で平熱に復した，下痢便の性状は，泥状ないし水射状で 一部に血便もみられた。 下痢は一過性で活とんぞが 2 3 日で回復した.

発生農家に特いては 5 ３0\% の 泌乳量の 減少がみら

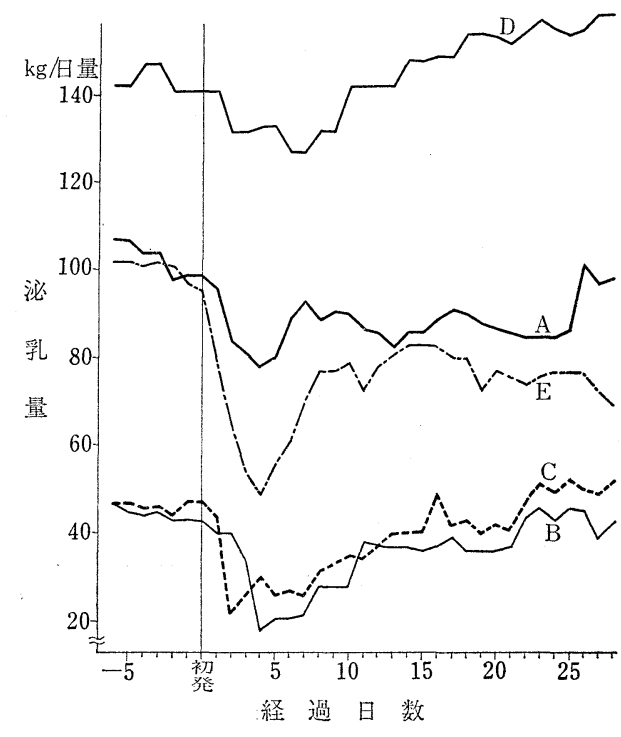

図 1 農 家別泌乳量 の推移 
牛コロナウイルス感染による成牛の伝染性下痢症の発生例

袁3- 般臨休所見

\begin{tabular}{|c|c|c|c|c|c|c|c|c|c|c|c|c|c|}
\hline \multirow{2}{*}{ 牛 No. } & \multicolumn{2}{|c|}{ 下浰発生 体 温 } & \multirow{2}{*}{\multicolumn{2}{|c|}{ 下痢便の性状 }} & \multirow{2}{*}{ 食欲減退 } & \multirow{2}{*}{ 白血球数 } & \multicolumn{6}{|c|}{ 白血球百分比（\%） } & \multirow{2}{*}{$\begin{array}{l}\text { 回復後の } \\
\text { 白血球数 }\end{array}$} \\
\hline & 後の日数 & $\left({ }^{\circ} \mathrm{C}\right)$ & & & & & Bas & Eos & Sta & Seg & Lym & Mon & \\
\hline 1 & 3日 & 39.2 & 水 射 & 性 & - & 7,500 & 0 & 8 & 4 & 47 & 34 & 7 & 6,500 \\
\hline 2 & 3 & 38.7 & 泥 & 状 & + & 5,900 & 0 & 1 & 6 & 48 & 41 & 4 & 9,500 \\
\hline 3 & 4 & 38.3 & 泥 & 状 & + & 6,300 & 0 & 9 & 3 & 12 & 71 & 5 & 10,500 \\
\hline 4 & 2 & 41.8 & 水 射 & 性 & - & 6,100 & 1 & 5 & 13 & 44 & 35 & 2 & 7,100 \\
\hline 5 & 2 & 41.7 & 水 射 & 性 & + & 4,400 & 2 & 7 & 7 & 13 & 67 & 4 & 9,900 \\
\hline 6 & 3 & 38.6 & 水 射 & 性 & + & 4,900 & 2 & 2 & 4 & 14 & 78 & 1 & 7,000 \\
\hline 7 & 3 & 41.8 & $\begin{array}{l}\text { 水射性, } \\
\text { 血液を混 }\end{array}$ & $\begin{array}{l}\text { 粘液 } \\
\text { 无ず }\end{array}$ & + & 3,300 & 0 & 2 & 10 & 22 & 36 & 0 & 10,900 \\
\hline
\end{tabular}
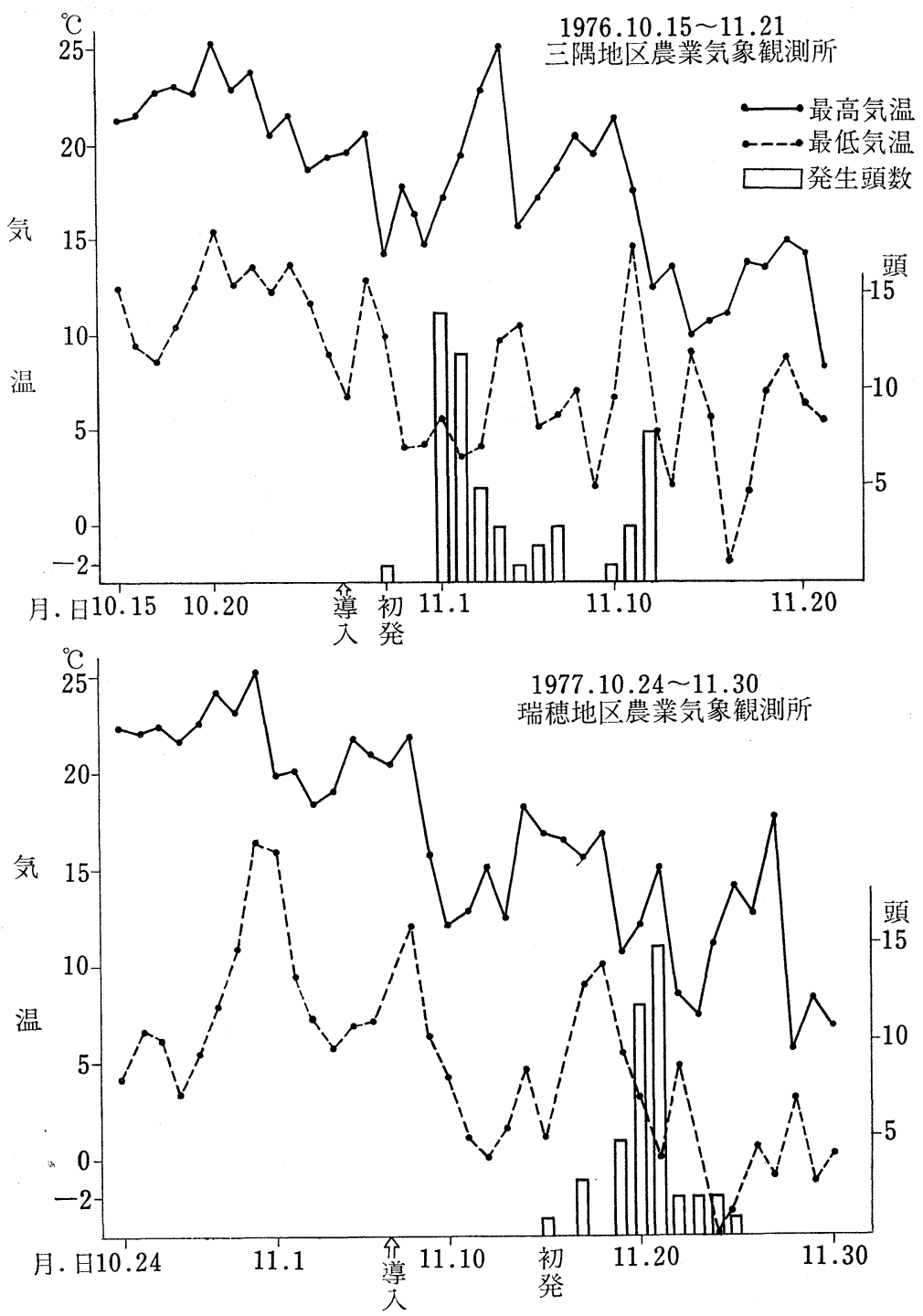

図 2 発生と気温と の 関 係

れ，減少の程度およびその期間は農家間に差がみられ 量の推移は図 1 に示すと扣りであった. B・C特よびD

た. 発生例 1 の農家のらちA〜 Eの 5 戸の農家別総泌乳 農家は打括むね $2 \sim 3$ 週間で発生前の泌乳量に回復した 
白石忠昭 原田清志 高瀬守史 垣崎一則 栗原宏治 原 文男 岩田明敏

表 4 既 知病原ウイルスに対する抗体検查成績

\begin{tabular}{|c|c|c|c|c|c|c|c|c|c|c|c|c|c|}
\hline \multirow{2}{*}{$\begin{array}{l}\text { 農 } \\
\text { 家 }\end{array}$} & \multirow{2}{*}{$\begin{array}{c}\text { 牛 } \\
\text { No. }\end{array}$} & \multicolumn{2}{|c|}{ P I V-3 } & \multicolumn{2}{|c|}{$\mathrm{Ad} \mathrm{V}-7$} & \multicolumn{2}{|c|}{ BVDV } & \multicolumn{2}{|c|}{ I B R V } & \multicolumn{2}{|c|}{ BR V } & \multicolumn{2}{|c|}{$\mathrm{BCV}$} \\
\hline & & $*$ 前 & 後 & 前 & 後 & 前 & 後 & 前 & 後 & 前 & 後 & 前 & 後 \\
\hline \multirow[t]{2}{*}{$\mathrm{A}$} & 1 & 20 & 20 & 20 & 20 & $<2$ & $<2$ & $<1$ & $<1$ & 80 & 40 & 160 & 640 \\
\hline & 2 & $<10$ & $<10$ & 20 & 20 & $<2$ & $<2$ & $<1$ & $<1$ & 10 & 20 & 320 & 320 \\
\hline $\mathrm{B}$ & 3 & $<10$ & $<10$ & $<10$ & $<10$ & $<2$ & $<2$ & $<1$ & $<1$ & 10 & 10 & NT** & NT \\
\hline \multirow[t]{4}{*}{$\mathrm{C}$} & 4 & 20 & 20 & $<10$ & $<10$ & $<2$ & $<2$ & $<1$ & $<1$ & 20 & 20 & 80 & 640 \\
\hline & 5 & 20 & 20 & $<10$ & $<10$ & $<2$ & $<2$ & $<1$ & $<1$ & 20 & 40 & 10 & 640 \\
\hline & 6 & 20 & 20 & $<10$ & $<10$ & $<2$ & $<2$ & $<1$ & $<1$ & 10 & 80 & 40 & $\geqq 2,560$ \\
\hline & 7 & 40 & 20 & $<10$ & $<10$ & $<2$ & $<2$ & $<1$ & $<1$ & 40 & 40 & 10 & 640 \\
\hline \multirow[t]{2}{*}{$\mathrm{D}$} & 8 & 40 & $<10$ & $<10$ & $<10$ & $<2$ & $<2$ & $<1$ & $<1$ & 10 & 10 & 10 & 640 \\
\hline & 9 & $<10$ & $<10$ & $<10$ & $<10$ & $<2$ & $<2$ & $<1$ & $<1$ & 20 & 10 & $\mathrm{NT}$ & $\mathrm{NT}$ \\
\hline \multirow[t]{4}{*}{$\mathrm{H}$} & 10 & 10 & 10 & 40 & 40 & \multirow{4}{*}{$\mathrm{NT}$} & \multirow{4}{*}{$\mathrm{NT}$} & $<1$ & $<1$ & 40 & 40 & 80 & 80 \\
\hline & 11 & 20 & 10 & $<10$ & $<10$ & & & $<1$ & $<1$ & 10 & 20 & 20 & 320 \\
\hline & 12 & 20 & 20 & $<10$ & $<10$ & & & $<1$ & $<1$ & 20 & 80 & 10 & 320 \\
\hline & 13 & $<10$ & 20 & $<10$ & 40 & & & $<1$ & $<1$ & 20 & 40 & $<10$ & 320 \\
\hline
\end{tabular}

* 前は発症中, 後は回復後をあらわす ** 検査せず

が，Aおよび $\mathrm{E}$ 農家は完全に回復しなかった。

血液検査ではほとんど全頭に白血球減少がみられ，と くに No. 7 ・5 㘧よび 6 に著しい減少がみられた。白 血球の百分比検查では, No. $5 \cdot 4 \cdot 6 \cdot 3$ 和よび 7 に 好中球の核の左転がみられた(表 3 ).

\section{4. 発生亡気温之の関係}

発生例 1 および 2 の発生時の気温は, 図 2 に示したと おり, 最低気温が急激に低下し, 最高気温と最低気温と の日差がきわめて大であった。

\section{5. ウイルスおよび細菌検査成績}

下痢便からのウイルス分離を試みた結果，BK执よび B T培養細胞にC P Eを認めず，その培養液は，鷄，牛 赤血球に対し $\mathrm{HA}$ 性を有しなかった.

下痢便の細菌培養検查においては，全例に大腸菌の純 培養状の発育が認められたが，サルモネラ，その他の細 菌は1例も分離されなかった。

\section{8. 既知病原ウイルスに対する抗体検査成績}

P I V-3，Ad V-7K対し発生例 1 の 1 頭, C R V K 対し発生例 1 和よび 2 のそれぞれ 1 頭計 2 頭に抗体価の 有意の上昇が認められた。 I B R V ，BVDVに対して は全頭抗体陰性で，抗体価の有意の上昇を示したものは 1 頭も認められなかった。これに反し，BCVに対して は, 発生例 1 に打いては 7 頭中 6 頭, 発生例 2 に打いて は 4 頭中 3 頭, 計 11 頭中 9 頭 $(81.8 \%)$ ときわめて高 率に抗体価の有意の上昇が認められた(表 4 ).

\section{考察}

B C Vは Stair $5^{16)}$ (1972), Mebus $5^{8 \sim 10)}$ (1972, 1973), SharpeE ら ${ }^{14)}$ (1976) により，米国に秥いて新 生子牛下痢症 (Neonatal calf diarrhea) の原因ウイルス として報告された.
稲葉 ${ }^{3)}$ は 1973 年に全国的に採取した成牛血清につい て，B C Vに対するH I 抗体保有状況を調査したとこ ろ，235頭中 221 頭 $(94.0 \%)$ が抗体陽性で，わが国の牛の 間にも本ウイルスが広く浸潤していると報告している.

高橋ら ${ }^{17}$ は, 1976 年 11 月から 1977 年 2 月に発生し た成牛の下疮症の下痢便について，電子顕微鏡観察特よ び免疫電顕法を試みた結果，コロナウイルス粒子を確認 し，さらに B K 細胞で B C Vを分離し得たことから， B C V は成牛の下痢症の原因ウイルスであると報告して いる.

島根県下に特いて 1976 年 10 月执よび 1977 年 11 月，牛を導入した農家に打いて発生した成牛の下痢症 は, 発生状況, 臨床症状, 血液検査成績などから, ウイ ルス感染が疑われ, 抗体検查の結果, 発症牛 11 頭のう 占 9 頭 $(81.8 \%)$ に B C V に対する抗体価の有意の上昇 が認められ，B C V 感染によるものと診断された。

B C V に対する抗体検査を実施した発症牛 11 頭のら ち 2 頭に抗体価の上昇が認められなかったことについて は, 前血清の抗体価がすでに 320 特よび 80 で，きわめ て高い抗体を保有していたことに起因すると考学られ た。

稲葉ら ${ }^{2)}$ は， B C V は牛胎児腎由来細胞である B E K -1 培養細胞で C P E を伴ってよく増殖すると報告して いる。京た稲葉ら C R Vの検出には，下痢便を精製濃縮して直接電顕でウ イルス粒子を観察する方法, 免疫電顕法, 補体結合反応 による特異抗原の検出, 螢光抗体法による特異螢光抗原 の検出などを行なうことにより，ＣＰＥが出現しなくて もウイルス増殖の有無を知ることができ, 検出率が高く なると報告している.

著者らが今回行なったウイルス分離法は, これらの点 
牛コロナウイルス感染による成牛の伝染性下痢症の発生例

から考皃ると, 分離に用いた培養細胞就よび分離の方法 梁不適当であったものと思われ，そのためにウイルス分 離陰性の成績に終わったものと推察される.

今回の発生例に㧤いては, いずれも牛を尊入した農家 に和いて, 導入後, 在来の同居牛にのみ発生がみられ, 導入牛には 1 頭も発症がみられなかった. その理由につ いては，導入牛の抗体検査を実施しなかったので，明ら かにすることができなかった. 発生が導入農家のみにみ られたことより，B CVが導入牛によって持ち込まれ， 感染発症に至ったものと推察される.

清水ら ${ }^{15)}$ は, 豚のコロナウイルス感染症である伝染性 胃腸炎（TGE）に括いて, 発症には環境温度の変化が 重要な因子であると報告して和り，また従来から成牛の 下痢症は冬期に発生が多くみられてきた. 今回の発生例 について気温の変化をみると, いずれも導入後から発症 時にかけて最低気温が急激に低下し，かつ最高気温と最 低気温との日差が大きかったことは，牛に拈けるコロナ ウイルス感染に拈いても, 脙のTGEと同様に, 環境温 度の変化が, 誘因の一つになり得る可能性を示唆するる のと思われた。

\section{ま と め}

1976 年 10 月就よび 1977 年 11 月の 2 度にわたり, 乳用牛を導入した酪農家に和いて, 在来の成牛に下痢症 が発生し，検査を行なった結果，以下の成績を得た.

1）下痢症は導入農家 9 戸の5ち 7 戸(発生例 1)，11 戸のうち 2 戸（発生例 2 ）に発生した.

2）下痢症発生農家に扣いては, 導入牛には発生せ ず, 在来の同居牛のみに発生し, 発生率は 59/85 頭, $69.4 \%$ (発生例 1) および $43 / 76$ 頭, $56.6 \%$ (発生例 2) であった.

3）導入から初発までの日数は，2日（発生例 1) お よび 7 日（発生例 2) であった.

4）本症の扣もな症状は, 元気消失, 食欲減退ないし 廃絶, 発熱, 激しい水射性下痢, 泌乳量の減少などであ った。

5）血液検査に括いては, 白血球数の減少执よび好中 球の核の左転がみられた。

6） B KおよびBT培養細胞によるウイルス分離は陰 性であった。下痢便の細菌培養検査に执いては, 大腸菌 のみが分離され, サルモネラ, その他の細菌は分離され なかった。

7） 6 種の既知病原ウイルスの抗体検査に括いて, B CVK対し 9/11 頭（81.8\%）に抗体価の有意の上昇 が涩められ，本ウイルスの感染が示唆された。

8）発生は両例とも 11 月上旬の気温の低下する時期 にみられた。導入から初発までの間に, 最低気温が急激 に低下し, 最高気温と最低気温との日差が大きかった。
終わりに，ご指導とご援助を賜った農林水産省家畜衛 生試験場の稲葉右二博士ならびに高橋英司博士に深甚な る謝意を表します。

〔本稿の要旨は昭和 53 年度日本臨床獣医学会 (中国) に拉いて報告した.」

$$
\text { 文献 }
$$

1) 稲葉右二：日獣会誌，24, 321～325 (1971).

2) InABA, Y., et al.: Arch. Virol., 50, 339 342 (1976).

3) 稲葉右二 : 臨床とウイルス, 5, 63〜65 (1976).

4) InABA, Y., et al.: Microbiol. Immunol., 21, 531 534 (1977).

5) 稲葉右二：日獣会誌，31，127～135 (1978).

6) 児玉和夫, 佐々木文存, 福山新一, 出水田昭弘, 石井富士雄 : 日本獣医育産大学紀要, 第 23 号, 51 $\sim 60$ (1974).

7) 岸 茂, 石井重子: 第 80 回日本獣医学会講演要 旨, 38 (1975).

8) Mebus, C. A., White, R. G., Stair, E. L., Rhodes, M. B. and Twiehaus, M. J.: Vet. Med. Small Anim. Clin., 67, 173 178 (1972).

9) Mebus, C. A., White, R. C., StajR, I. L., Rhodes, M. B. and Twiehaus, M. J.: Am. J. Vet. Res., 34, 145 150 (1973).

10) Mebus, C. A., Stair, E. L., Rhodes, M. B. and Twiehaus, M.J.: Vet. Pathol., 10, 45 64(1973).

11) 西間庭正士, ほか：日獣会誌, 25, 600〜604(1972).

12) SAто, K., et al.: Vet. Microbiol., 2, 73 81 (1977).

13) SAто, K., et al.: Vet. Microbiol., 2, 83 $\sim 87$ (1977).

14) Sharpee, R. L., Mebus, C. A. and Bass, E. P.: Am. J. Vet. Res., 37, 1031 1037 (1976).

15) Shimizu, M.: Shimizu, Y. and Kodama, Y.: Infect. \& Immun., 21, 747 752 (1978).

16) Stair, E. L., Rhodes, M. B., White, R. G. and Mebus, C. A.: Am. J. Vet. Res., 33, 1147 1156 (1972).

17) 高橋英司, ほか:第 84 回日本獣医学会講演要旨, 156 (1977).

18）田中義夫, 杉村崇明, 原 元宣, 稲葉右二, 黒木 洋, 大森常良: 第 76 回日本獣医学会講演要旨, 54 (1973).

\section{日獣の図書案内}

\section{犬の内科診断学}

東京農工大学助教授・医学博士 大石 勇著

定価 7,500 円（送料 300 円）

B 5 版 442 頁 写真 (カラー写真を含む)

図版多数插入 上製ケース入 